\title{
El Hierro Renewable Energy Hybrid System: A Tough Compromise
}

\author{
Grażyna Frydrychowicz-Jastrzębska \\ Department of Electrical Engineering, Poznan University of Technology, Piotrowo 3a Street, \\ 60-965 Poznań, Poland; grazynajastrzebska@op.pl; Tel.: +48-61-665-2388 or +48-66-163-4997
}

Received: 23 September 2018; Accepted: 15 October 2018; Published: 18 October 2018

\begin{abstract}
The Gorona del Viento project was characterized in this article, concerning its implementation, as well as several years of exploitation in an isolated location, namely on the El Hierro island. The hybrid system includes a wind farm and a pumped storage power plant, which acts as an energy storage, and all are equipped with a control system. The planned strategy assumed a configuration based on $100 \%$ wind energy supply. However, the system does not guarantee the anticipated effectiveness. The problems with the lack of energy self-sufficiency are partly the result of changes in the project made already during construction, in particular because of the mismatch of the water reservoir's capacity and the wind turbines' energy production efficiency. This results in the necessity to limit the wind farm capacity to ensure grid stability and hence requires supplementation of energy from the diesel generator. The author compared the object to analogical ones which employ different technological solutions and presented potential suggestions as to improve the existing state and achieve the reliability of the system's operation.
\end{abstract}

Keywords: renewable energy sources; energy self-sufficiency; hybrid system; energy storage; isolated locations

\section{Introduction}

Over the last twenty years, a number of initiatives related to the introduction of energy self-sufficiency in isolated locations have been observed [1-11]. Such attempts were successfully made on the islands of the Atlantic, Pacific, and Indian Oceans [1], the Azores, the Canary Islands, the Greek Islands, the Caribbean, Tokelau (New Zealand), Bornholm, Samsø (Denmark), the Galápagos Islands (Ecuador), Bonaire (Little Antilles, the Netherlands), American Samoa Islands, and many others. This is in addition to those in the center of the European continent, e.g., in Feldheim near Berlin (a separate system). The new solutions are, in most cases, based on hybrid systems of renewable energy sources.

Reference [2] reviews the research in the field of the design, optimization, operation, and control of renewable hybrid energy systems in isolated locations, and Reference [3] presents an analysis of the energy potential of isolated systems (with particular reference to wind energy) in relation to their population. The importance of hybridization and energy storage was also emphasized. Reference [4] contains information concerning energy solutions on El Hierro, Bornholm, Samso, Iceland, and Corvo. Assessment of the power system of the insular structures from the point of view of sustainable development and reliability and the feasibility of their implementation for the areas of Madeira, Porto Santo, Hawaii, Canary Islands (El Hierro, Lanzarote), Menorca, Azores Peak, and Vancouver Island were carried out in Reference [5]. The authors suggest worldwide cooperation between islands in the field of energy self-sufficiency and RES (Renewable Energy Sources). Analogous considerations with regard to the Azores and Canary Islands, as well as Danish and Greek islands are contained in Reference [6]. 
Reference [7] assessed the isolated electricity network and goals proposed in the Canary Islands energy plan (PECAN), taking into account the average cost and risk associated with different alternatives to electricity generation. In order to increase efficiency (even by $30 \%$ ), authors additionally suggest the use of natural gas. Current and future (until 2050) action plan in this area was presented in Reference [8]. Reference [9], on the other hand, presented the program of introducing RES in the Azores from 2007 to 2018. The smallest of the archipelago islands, Corvo, is planned to be powered exclusively from RES [4,9]. Reference [10] concerned the Greek islands of Crete, Kythnos, Ikaria, and Agios Efstrations. An interesting solution was applied on Ikaria (thermal, PV (photovoltaic), wind, and hydro with storage in two locations). The island of Agios Efstrations is planned to achieve $100 \%$ energy self-sufficiency only from RES. In Reference [11], the importance of assessing the technical and economic feasibility of isolated wind energy systems is emphasized.

Because of the instability of the RES (the availability of their potential depends on many factors), a reserve conventional source and a storage are often introduced into the system [4].

Reference [12] proposed a novel method of optimizing the efficiency of battery energy storage systems. Four optimal objective functions have been taken into account, such as minimum energy storage capacity, minimum load dump, the maximum lowest deflection frequency, and minimum disruption duration indicator.

An overview of possible solutions for electricity storage is presented in References [13-18] including pumped hydro storage, flywheel, superconducting magnetic energy storage (SMES), supercapacitors, battery energy storage system (BESS), pumped heat electrical storage (PHES), and compressed air energy storage (CAES), whereas in References $[13,14,16-18]$, the subject of the integration of storage systems with RES and application possibilities in insular systems were considered. Energy storage can increase the reliability of the microgrids. Reference [14] indicates that pumped hydro storage currently dominates in total installed power capacity storage (with $96 \%$ out of the total of 176 gigawatts installed globally until mid-2017); authors also considered the possibility of using flow batteries. Reference [17] suggests periodic use of electric car batteries for cooperation with RES.

\section{Selected Applications in Other Isolated Locations}

Studies have demonstrated that in the majority of locations, the achievement of the full energy self-sufficiency is an unrealistic purpose; the average annual percentage of renewable energy sources in the energy balance is estimated at the level between 30 and $80 \%$, e.g., in case of Graciosa Island, $65 \%$ is the estimated percentage $[19,20]$. However, RES energy self-sufficiency is possible on Tokelau, which is supplied with solar energy exclusively, and which distributes the energy surplus to the neighbouring islands [21]. It is also possible in in Feldheim [22], with the rich RES assortment and the largest accumulator in Europe [23], and on Samsø [24], which exports the wind energy surplus. Bornholm and Samsø may take advantage of the power supply from land by means of an underwater cable. In other isolated regions, the energy scarcity must be supplemented by the energy obtained from diesel oil, transported from the continent, which results in financial outlays and external costs $[4,24,25]$.

The problem of the lack of self-sufficiency can be partly eliminated by the strict observance of the energy supply and demand balance; the storage of surpluses; the smart energy management as it in the case of Bornholm, Samsø, and in Feldheim [4]; and in hybrid power plants with intelligent software, with the participation of VESTAS, e.g., in Spain, Poland, and Australia, the latter one with the target value of $1.2 \mathrm{GW}$ [26].

Similar activities are introduced in the Canary Islands. The purpose is to ensure the full energy self-sufficiency of the archipelago by the year 2050. Furthermore, there are plans to provide energy connections using an underwater cable between the islands to ensure an energy balance, e.g., between the islands of El Hierro, La Palma, and La Gomera [8]. 
The role of integration between individual energy sources is emphasized in Reference [27] on the example of São Miquel in the Azores. The considerations concern the heat and power plant, two geothermal power plants, a hydroelectric plant, a wind farm, and a conventional source. The possible inclusion of a photovoltaic installation in the system was also analyzed. An innovative serial model has been proposed for the main energy plan on the São Miguel Island. Based on the algorithm, it has been shown that optimizing and maximizing the integration of renewable energy sources reduces fuel consumption, production costs, and greenhouse gas emissions.

The Terceira system is difficult to implement because of the greater variety of cooperating RES and the necessity of their integration. For the year 2018, based on the estimated scenario of energy demand and supplies, geothermal energy, wind energy, thermal energy, and recovery of energy from bio-waste were taken into consideration. In the case of Terceira, a detailed analysis of different storage solutions was conducted. It was demonstrated that the optimal storage of energy will be ensured using a pumped hydro storage. The cost of PHS (Pumped Hydro Storage) is much lower than in the case of battery-based solutions [28].

Reference [29] presents the integration of components: wind, diesel, and hydro turbines in the Flores Island. The addition of the FESS (flywheel energy storage system) improved the stability and allowed the higher penetration of energy from renewable sources, and as a consequence of this, a reduction in the consumption of oil. The system was evaluated after one year of its operation.

Other hybrid systems in the isolated locations are also supplemented with energy storage, e.g., Graciosa (3.2 MWh lithium-ion storage in the Younicos system) connected with the PV power plant (1 MW) and a wind farm (4.5 MW) [19]; Tokelau (energy storage in a lead-acid battery, a total of 1344 batteries) [21]; and Feldheim (lithium-ion battery with a total capacity of $10 \mathrm{MW}$ and a power of $10.8 \mathrm{MWh}$ [23].

In the hybrid system, which consists of three wind turbines and two sets of PV modules in San Cristóbal, the Galápagos Islands (Ecuador), from the moment of commissioning in October 2007 up to and including 2015, the average percentage of wind energy reached $29.2 \%$, when compared to diesel's $70.8 \%$. The reduction in the $\mathrm{CO}_{2}$ emissions during the above-mentioned period was 21,254 tonnes. The lowest share of diesel in the energy generation was observed in the years 2012 and 2015. In the wind farm on the Galápagos Islands, lead-acid and lithium-ion batteries were used to balance the load. The Galápagos project also covers two $6 \mathrm{kWp}$ PV installations, which generated 136,000 kWh of energy, as well as new transmission lines and advanced control systems that allow the integration and cooperation of the entire system [30].

Initially, the Bonaire system did not cover the FESS, and the aim was the achievement of the wind penetration rate at the level of $40-45 \%$. In the absence of energy, a diesel generator with bio-oil from marine algae is used [31].

In the seven-island archipelago of American Samoa, electricity is obtained from wind, solar, geothermal, and biomass energy. Tesla installed two powerpack battery systems and implemented the island network control software, which is to control the integrated 13.6 MWh system of energy production and storage [32,33].

The Greek Ikaria relies on the wind-water system with two water storages (3.1 MW and $1 \mathrm{MW}$ ), located in different towns $[4,10]$.

Each of the solutions requires specific conditions and uses different renewable energy sources, though on the Atlantic islands, the wind energy is by far the most popular [8,9]. It is also important to select the storage capacity properly, while the installation per se should not be over-dimensioned

Examples of wind farms on the Atlantic islands are presented in Figure 1. 


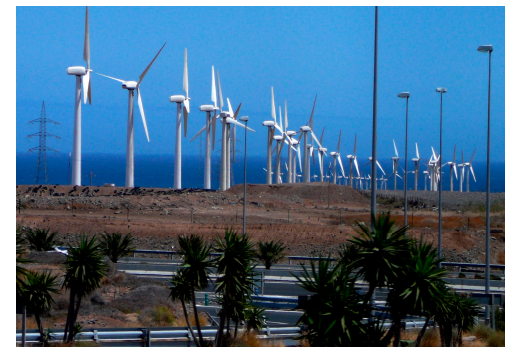

(a)

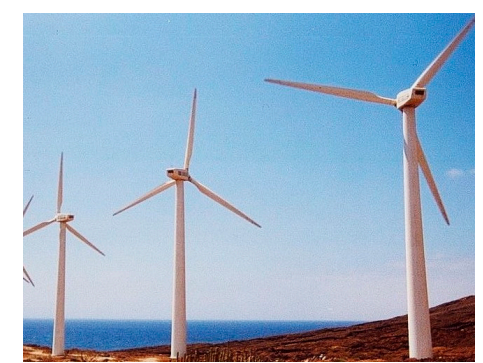

(b)

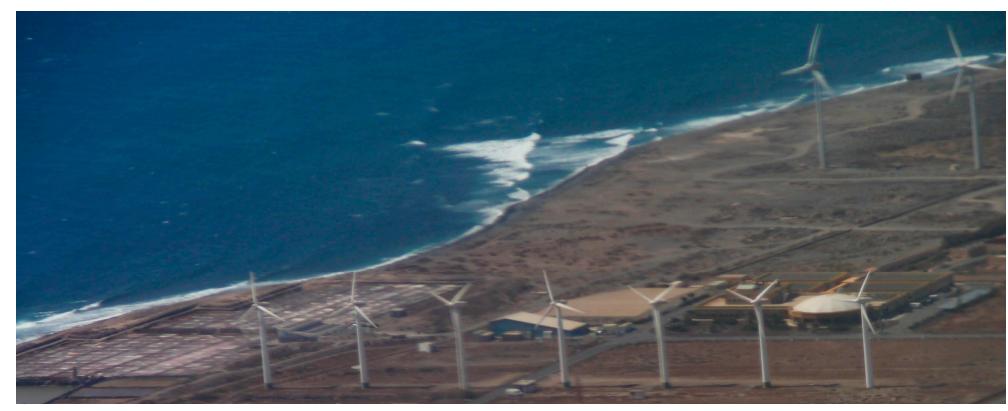

(c)

Figure 1. Examples of wind farms in isolated locations: (a) Gran Canaria, (b) Tenerife, and (c) Terceira. Photo: G. Jastrzębska.

\section{Biosphere Reserve and Gorona del Viento Project}

On 10 January 2007, the European Commission presented the Climate and Energy Package to the member states, which concerned a decrease in the emission of greenhouse gases and an increase in the share of renewable energy sources in the final energy consumption and effectiveness.

The locations isolated in terms of energy include El Hierro (Isla del Meridiano), the smallest among the Canary Islands, recognised by UNESCO in the year 2000 as a biosphere reserve and geological park, and in the La Restinga region, a marine reserve was isolated (Figure 2).

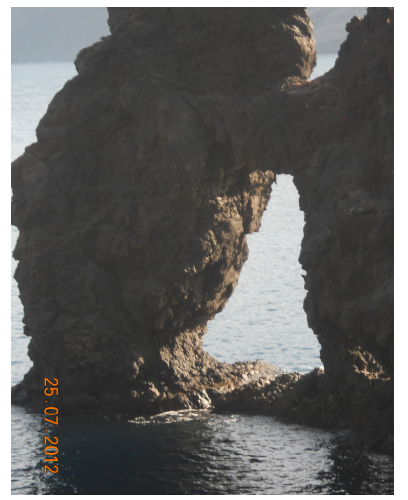

(a)

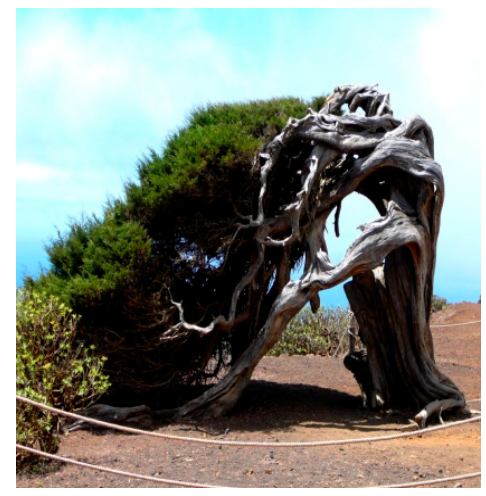

(b)

Figure 2. El Hierro UNESCO Biosphere Reserve: (a) Roque de la Bonanza, (b) juniper tree at El Sabinar under the influence of strong wind. Photo: G. Jastrzebska.

The area of El Hierro is mountainous, and the landscape is diverse because of pine forests with steep cliffs (on the shore, the area reaches $1500 \mathrm{~m}$ above sea level) and geological formations with rock basins [34-39]. The island is scarcely populated during the entire year; the area of $278 \mathrm{~km}^{2}$ is inhabited by $7000-10,000$ people (36 people per $\mathrm{km}^{2}$ ).

Initially, the energy demand of the island was secured by electricity produced from diesel oil. The oil in the amount of 6000 tonnes per year was transported to the island with a tanker (the costs amounted to EUR 2,000,000) [4]. 
According to the plans, by the year 2050, all the islands of the archipelago will be $100 \%$ supplied with renewable energy sources. The strategy provides for the $20 \%$ share of RES in the energy balance by the year 2020 and by the year 2030, this share will be $58 \%$ [8].

The aspects listed in the first section, i.e., self-sufficiency and ecology, as well as financial considerations, justified the introduction of a new energy model on the island of Gorona del Viento [40]. Its task would be to satisfy the needs of the inhabitants by means of renewable energy sources. There were plans to install a wind farm in combination with the existing UNELCO-ENDESA (This is cooperation of two companies: Empresa Nacional de Electricidad-ENDESA and Union Electric Company-UNELCO) system and the pumped hydro storage, which was supposed to fulfil the role of an energy storage in the case of wind energy scarcity.

The topography of the island is advantageous for the completion of this investment. The peak of an extinct volcano was the suitable place for the location of wind turbines. The geographical location of the island guaranteed high wind levels of 7.24-8.42 m/s [40,41]. The highest wind speed of $30.8 \mathrm{~m} / \mathrm{s}$ was recorded in 2017 [40]. An additional advantage was the possibility of using the La Caldera crater as a natural (upper) reservoir of the hydro-electric power plant [40].

The first projects related to the integration of the wind park with the pumped hydro storage were developed in the 1980s.

Reference [42] refers to an innovative strategy of operation on the El Hierro island and obtaining a reliable and efficient energy system working exclusively using RES. The advantages of connecting a pumped storage power plant to stabilize the power supplied by a wind farm are presented. The solution allows for the regulation of the system and store large amounts of energy, and consequently reduces dependence on conventional fuel. Energy stored during windy periods can be transformed into electricity when the load exceeds the current energy generated from the wind by means of a hydraulic turbine. The results of the presented research can be extrapolated to other networks in order to estimate the needed percentage of conventional power in the system, depending on the available wind power. The terrain intended for the investment is shown in Figure 3.

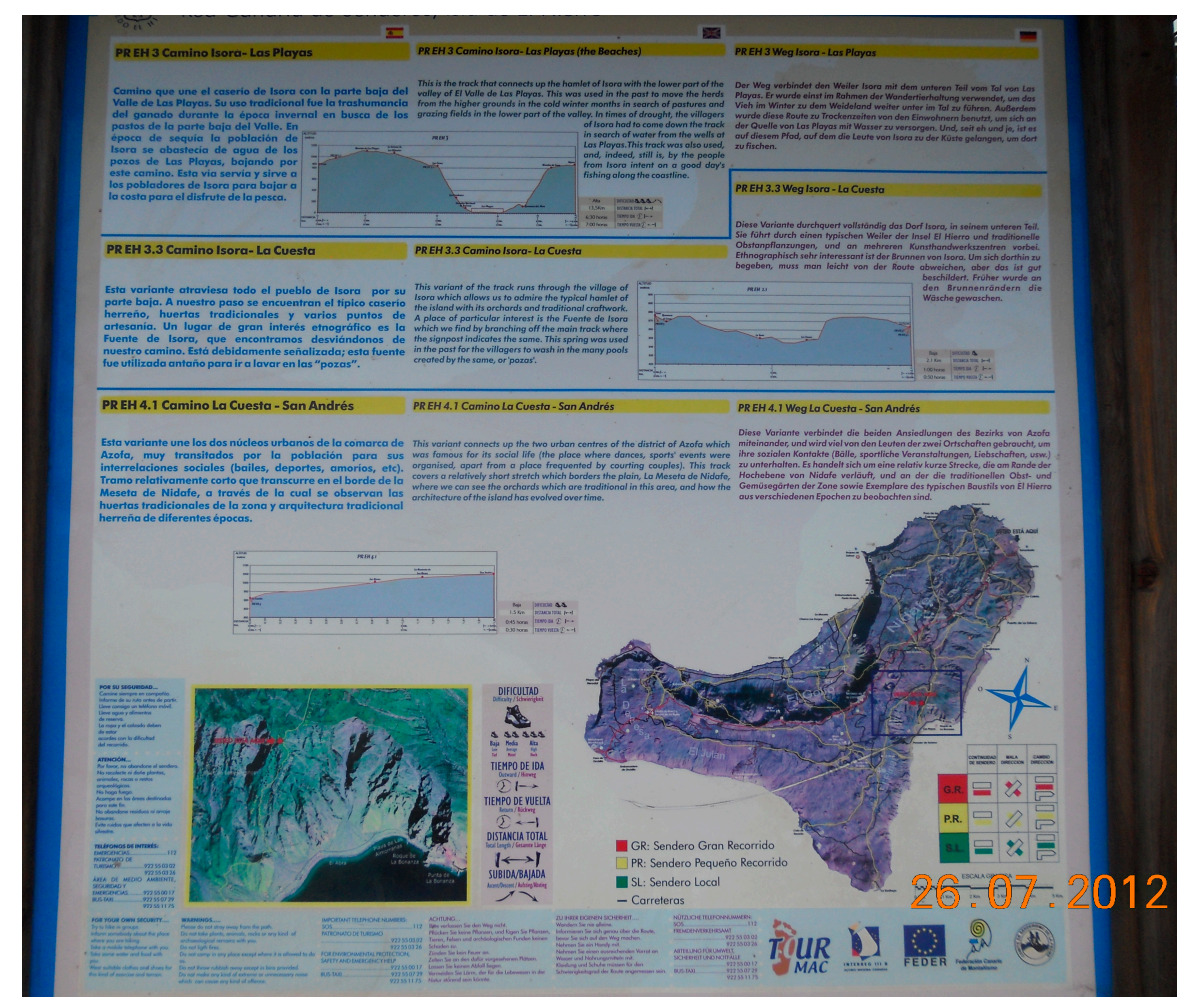

Figure 3. El Hierro UNESCO Biosphere Reserve with landform and technical documentation, Photo: G. Jastrzębska. 
The selected concept is innovative. The pumped hydro storage does not provide "support" for the wind energy, it is rather the wind energy that ensures the pumped hydro-accumulation, allowing the functioning of the hydroelectric plant as the source of the load [43,44].

The technical feasibility study was performed and the optimal configurations of wind generators, hydraulic turbines, and devices for volumetric placement were determined. The support from the European Union as well as the central and local authorities was gained. The location of the investment co-financed from the budget of the El Hierro Island Council (65.82\%), Endesa (23.21\%), The Canary Islands Institute of Technology (7.74\%) and the Autonomous Community of the Canary Islands (3.23\%) was planned in the La Caldera Valverde district $[4,40]$.

The Gorona del Viento Company was established in the year 2004. Construction works were started in the year 2009 upon obtaining a permit from the local authorities and conducting the environmental clearance [40].

\section{System Arrangement and Operations Details}

The finally integrated system consisted of the wind farm, the hydroelectric power station, and the pumped storage system. The wind farm was located at a distance of $2.5 \mathrm{~km}$ from the hydroelectric plant [45]. It must be mentioned here that this is the first such project in the power scale given in megawatts [40].

Figure 4 presents the planned layout of the facilities.

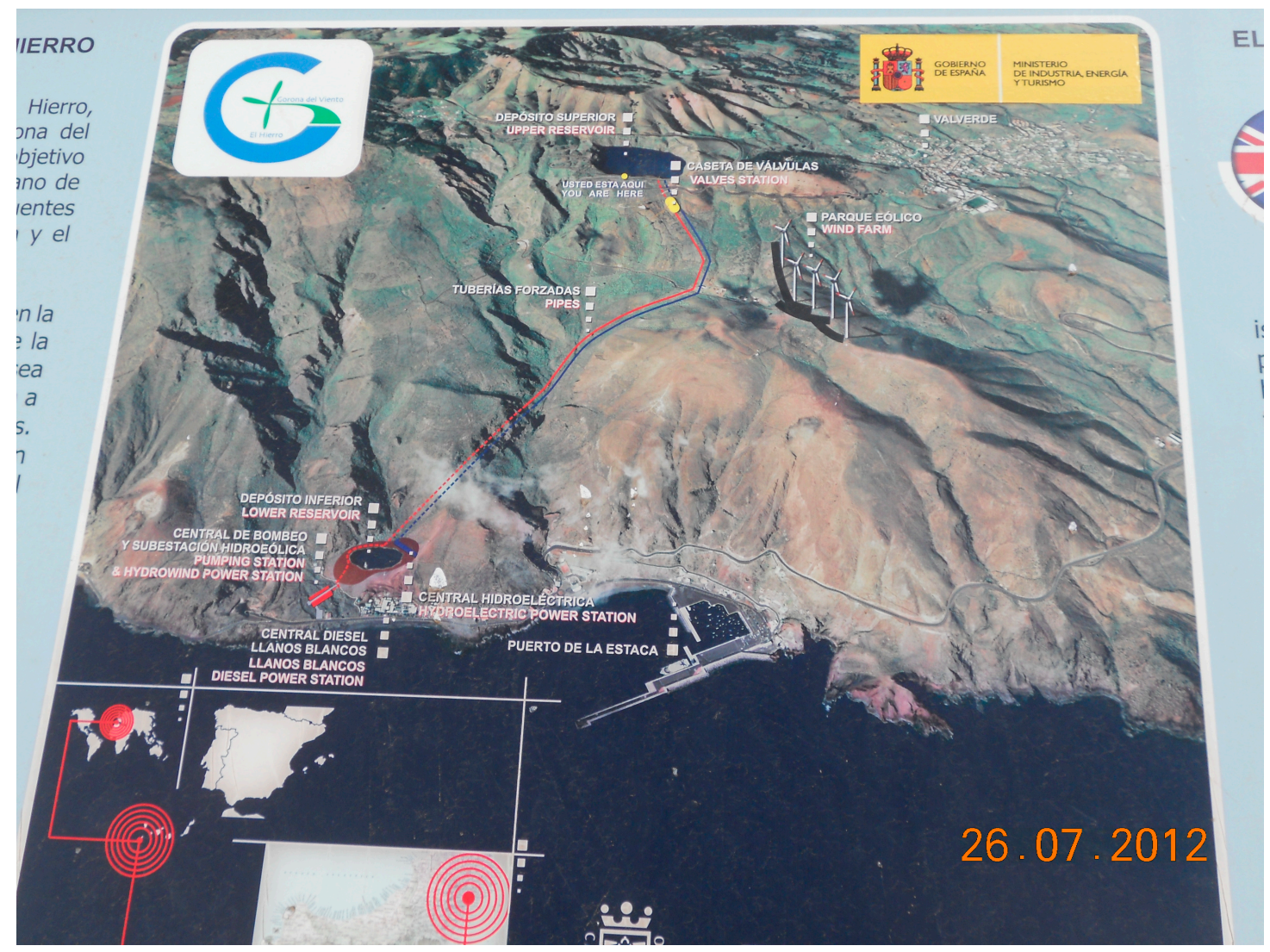

Figure 4. Information board presenting implementation of the Gorona del Viento Project with planned location of the objects. Photo: G. Jastrzębska.

The farm consists of five ENERCON E-70 turbines (ENERCON GmbH, Name of the Company dealing with wind energy plant) with a total installed power of $11.5 \mathrm{MW}$. Electricity obtained directly from wind is used for the needs of the inhabitants and for the water desalination plant $[4,40,45]$. 
One advantage of the ENERCON E-70 solution is that wind energy converters are started with a special storm control feature. This slows down the turbine, owing to which it can still function at high wind speeds. The turbine switches off only at a wind speed higher than $34 \mathrm{~m} / \mathrm{s}$ (10-min average [46].

Table 1 contains the values of construction-operational parameters for ENERCON E-70 wind turbines, used at Gorona del Viento on El Hierro [46].

Table 1. Parameters of ENERCON E-70 E4 wind turbines.

\begin{tabular}{|c|c|c|}
\hline Parameter & Unit & Value \\
\hline rated power & $\mathrm{kW}$ & 2300 \\
\hline hub & - & steel tube concrete \\
\hline hub height & $\mathrm{m}$ & 64 \\
\hline rotor diameter & $\mathrm{m}$ & 71 \\
\hline blade material & - & $\mathrm{GRP}^{1}$ \\
\hline number of blades & - & 3 \\
\hline swept area & $\mathrm{m}^{2}$ & 3959 \\
\hline rotational speed (var.) & $\mathrm{rpm}$ & $6-21$ \\
\hline cut out wind speed & $\mathrm{m} / \mathrm{s}$ & $28 / 34^{2}$ \\
\hline wind zone (DIBt) & - & III \\
\hline wind class (IEC) ${ }^{3}$ & - & I A \\
\hline remote monitoring & - & ENERCON SCADA \\
\hline
\end{tabular}

${ }^{1}$ fibreglass, epoxy resin, built in lighting protection, ${ }^{2}$ with ENERCON storm control, ${ }^{3}$ classification according to IEC (International Electrotechnical Commision), has four classes defining the intensity of turbulence. SCADA: Supervisory Control and Data Acquisition, informatic system that supervises the course of a technological or production process.

Figure 5 shows the characteristics of the turbine power versus wind speed.

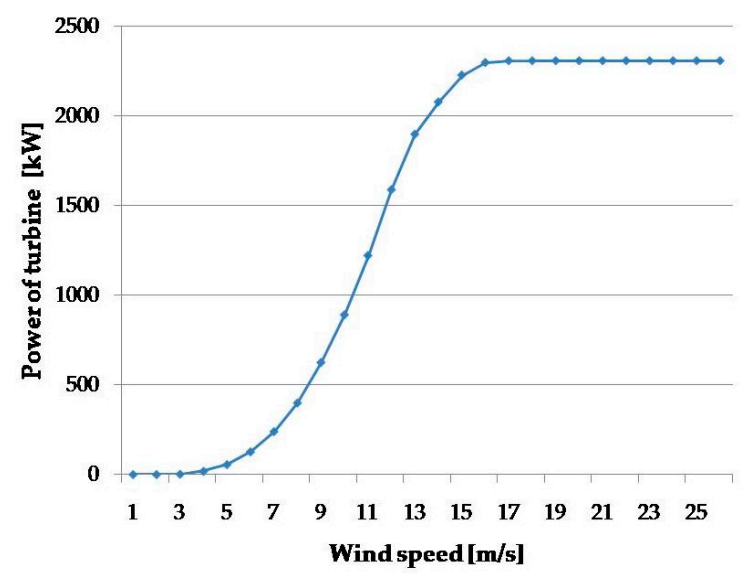

Figure 5. Power characteristics of the ENERCON E-70 turbine as a function of wind speed, own elaboration based on Reference [47].

The second part of the system, the pumped hydro storage with a total power of $11.3 \mathrm{MW}$, included four Pelton turbines, each with the unit power of $2.83 \mathrm{MW}$ connected with alternators with a power of 3.3 MVA. They are the development of the "spray wheel," in which the blades were set at an angle of $90^{\circ}$ towards the jet. In order to increase the efficiency, special profiled blades in the shape of two combined buckets were used. These were impulse turbines, therefore, the pressure at the inlet and outlet of the rotor was the same. In connection with the decision to disconnect the diesel generator, the Pelton turbines were modified to operate as rotary phase shifts (compensators), and their generators supplied the required short-circuit power and passive power to the grid. After the disconnection of the diesel generator, they were supposed to take over the control of voltage and frequency [40]. Another option of frequency control is proposed in Reference [48]. The performed simulations confirmed the justness of the measures taken. The natural crater of an extinct volcano was used as the reservoir. It is 
situated $650 \mathrm{~m}$ higher than the artificial reservoir (714.5 $\mathrm{m}$ above sea level). The lower reservoir with a capacity of $150,000 \mathrm{~m}^{3}$ is located near the area of the diesel power plant Llanos Blancos [45].

Figure 6 shows the draft of the project.

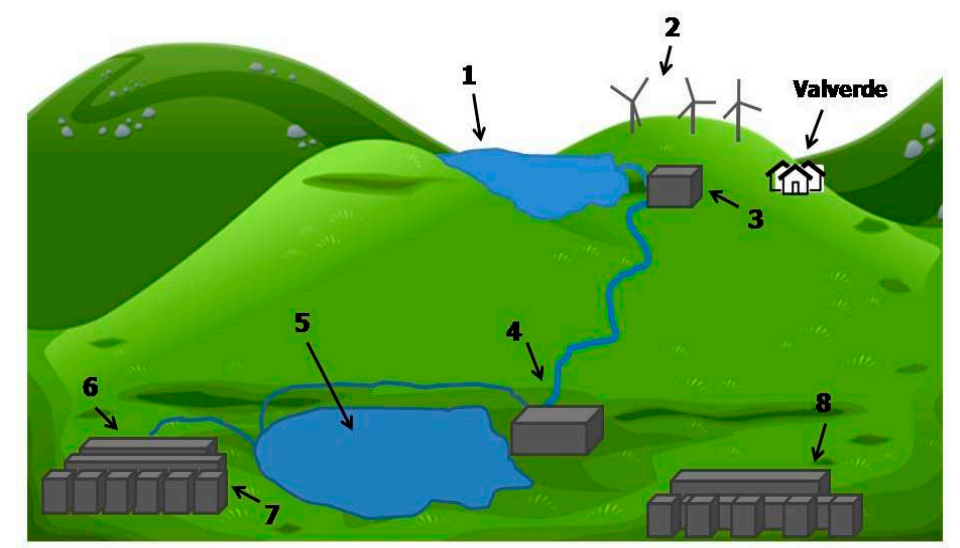

Figure 6. Sketch of the project implemented by the ABB (ASEA Brown Boveri) concern on the island of El Hierro with location of the wind-hydro power plant facilities (own elaboration). Signs: (1) La Caldera hydroelectric tank; (2) wind farm $5 \times$ ENERCON; (3) pumping station; (4) hydroelectric station $4 \times$ Pelton; (5) bottom tank; (6) pump station; (7) electrical substation with mutual connection between a wind farm, hydroelectric station and pump station; and (8) Llanos Blancos diesel power plant.

Selected parameters of the upper reservoir of the hydroelectric power plant are listed in Table 2.

Table 2. Structural and operational parameters of the upper hydropower plant [45].

\begin{tabular}{|c|c|c|}
\hline Parameter & Unit & Value \\
\hline reservoir capacity & $\mathrm{m}^{3}$ & 379,634 desalinated water ${ }^{1}$ \\
\hline the height of the summit ${ }^{2}$ & $\mathrm{~m}$ & 715 \\
\hline lower crater height & $\mathrm{m}$ & 698 \\
\hline compacting the bottom & - & $2 \mathrm{~mm}_{\text {geomembrane } \mathrm{HDPE}^{2}}$ \\
\hline waterproofing & - & geomembrane $\mathrm{PVC}^{3}$ \\
\hline flow & $\mathrm{m}^{3} / \mathrm{s}$ & 2 \\
\hline
\end{tabular}

The upper reservoir has two drain inlets, both made of S355NL steel and $530 \mathrm{~m}$ long. The suction from the lower reservoir took place through a steel culvert embedded in concrete, with a diameter of $1 \mathrm{~m}$ and length of $188 \mathrm{~m}$.

The parameters of the lower reservoir are described in Table 3 [45].

Table 3. Structural and operational parameters of the lower hydropower plant.

\begin{tabular}{ccc}
\hline Parameter & Unit & Value \\
\hline reservoir capacity ${ }^{1}$ & $\mathrm{~m}^{3}$ & 150,000 \\
the height of the barrier & $\mathrm{m}$ & 23 \\
water level & $\mathrm{m}$ & 15 \\
waterproofing & & $2 \mathrm{~mm}$ geomembrane $\mathrm{HDPE}^{2}$ \\
\hline${ }^{1}$ at $56 \mathrm{~m}$ above sea level, ${ }^{2}$ high density polyethylene.
\end{tabular}

The pumping station was characterised by the power of $6 \mathrm{MW}(2 \times 1.5 \mathrm{MW}$, connected with a variable speed drive and $-6 \times 0.5 \mathrm{MW}$, powered via induction motors. Adjustment of the power factor was by means of capacitors). The hydro system also included two transformers, 12 MVA each $(20 / 6 \mathrm{kV})$, and four compensation capacitors with a unit power of $350 \mathrm{kVA}$, connected to $6 \mathrm{kV}$ busbars. 
Another system component responsible for electricity generation in the system is the diesel unit (a conventional source that supplements the energy scarcity from renewable sources). The Central Diésel de Llanos Blancos plant had the maximum capacity of $12.73 \mathrm{MW}$ with the utilization factor of $38.2 \%$. It consisted of diesel groups with powers ranging between $0.775 \mathrm{MW}$ and $1.9 \mathrm{MW}$, and was fitted with alternators, transformers, and control devices [49]. According to Reference [18], the maximum capacity was estimated to slightly exceed $10 \mathrm{MW}$.

The investment comprised the ABB Distributed Control System (whereby its sensors responded within $5 \mathrm{~s}$ from the signal informing about waning of the wind), as well as the old and new grids [4].

The costs of the generation of electricity on the Canary Islands were high due to the necessity of combination of different technologies during its production. This required the assurance of the technical control with greater complexity, both the mains frequency and voltage, and a greater power reserve. However, the highest costs were generated by the use of the diesel oil, and the costs of wind energy generation in this region are twice as low [41]. The annual demand of the island for electricity is estimated preliminarily at the level of $35 \mathrm{GWh}$ (average load of $4 \mathrm{MW}$ ). A possible increase in the load, caused by an increase in the demand for energy up to $50 \mathrm{GWh}$ has been taken into account. There were predictions that El Hierro would be the first region in the world that would be $100 \%$ self-sufficient with regard to its energy needs $[35,50,51]$.

After preliminary simulations, the planned strategy for El Hierro required the preparation of the energy system which would rely $100 \%$ on wind energy, partly supplied to the grid after the conversion to electricity and partly converted into the energy stored in the pumped hydro storage. In the original version, it was assumed that $80 \%$ of wind energy would be used to pump in the water. However, it was found that the conversion of the kinetic energy of wind into potential water energy would be the cause of losses reaching even $40 \%$, which was a consequence of both the pumping process and the efficiency of the water turbines. Therefore, the final version assumed that only about $20 \%$ of wind energy was to be directed to the grid indirectly through the pumped hydro storage [40].

Figure 7 presents the information table regarding the respective investment stages.

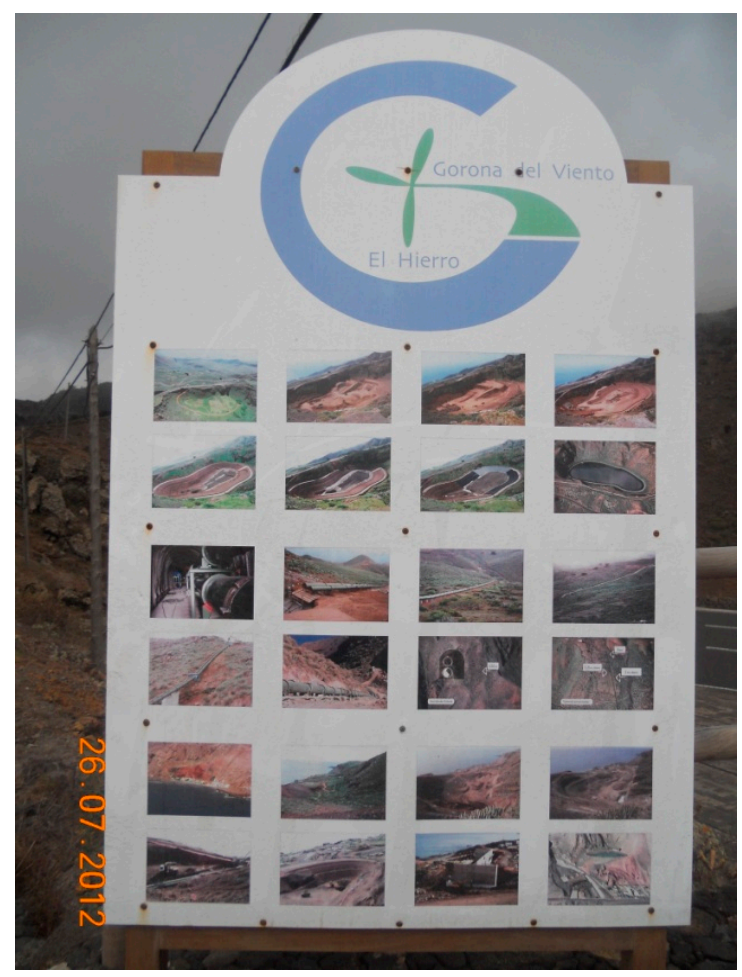

Figure 7. Information board presenting implementation of the Gorona del Viento Project. Photo: G.Jastrzębska. 
Figure 8 shows the wind farm in the El Hierro energy system.

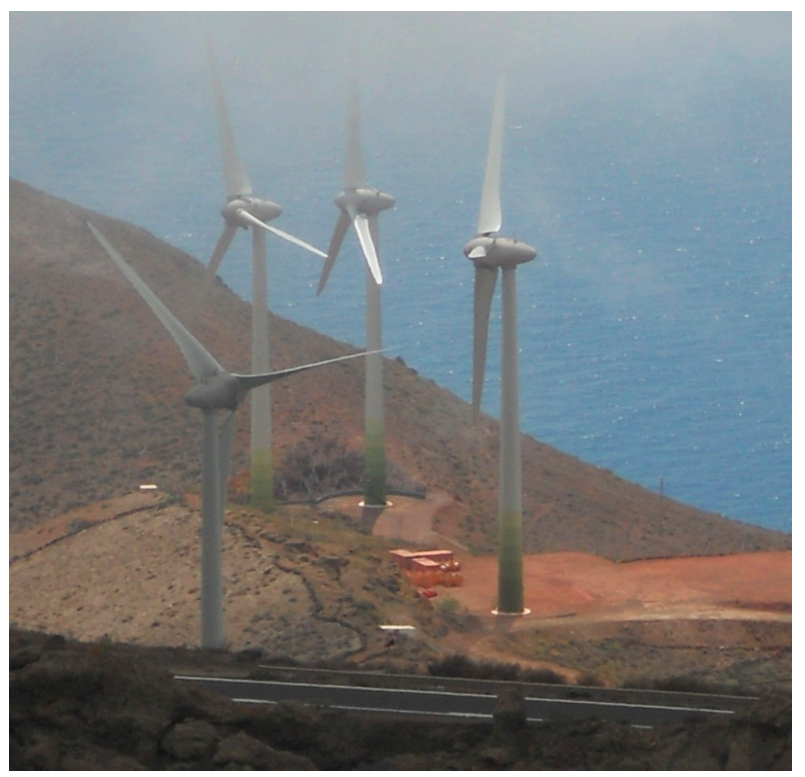

Figure 8. Wind power plant in the El Hierro hybrid power system where four of the five turbines are shown. Photo: G. Jastrzębska.

During the implementation of the project, the upper reservoir in the volcanic basin revealed the weakness of rock formations, which brought the threat of a disastrous leakage.

The problems with the leak-tightness of the reservoir located at the height of $600 \mathrm{~m}$ a.s.l. (above sea level) also occurred earlier in the case of the Laguna de Barlovento facility in La Palma. At that time, a membrane made of plasticized polyvinyl chloride (PVC-P) was used. Nineteen years after the installation, it was subjected to a comprehensive testing programme, which covered quantitative tests as well as the optical and scanning electron microscopy. The test results document the good condition of the geomembrane with initial degradation processes [52]. Detailed testing using the numerical modelling for the case of the reservoir in an old flooded quarry was described in Reference [53]. The impact of the processes in the water-bearing layer on the change in the water level was taken into account.

Figure 9 presents the view of the upper reservoir of the hydroelectric plant.

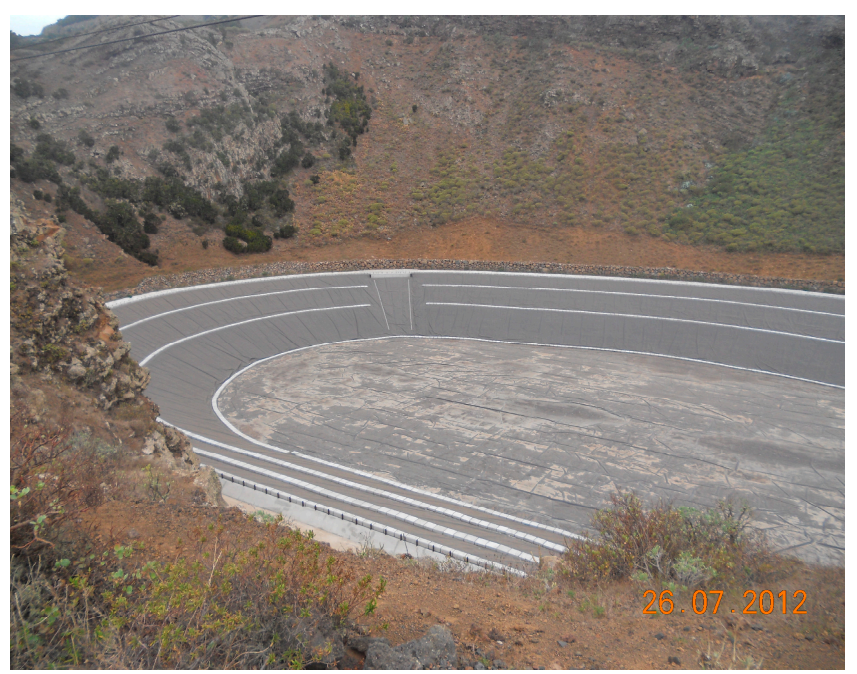

Figure 9. The upper reservoir of the hydropower plant. Photo: G. Jastrzebska. 
On the island of El Hierro, in the situation of the threat of leakage, the capacity of the upper reservoir was reduced from $550,000 \mathrm{~m}^{3}$ to $379,634 \mathrm{~m}^{3}$ (Table 2). The maximum water level reached $12 \mathrm{~m}$. In addition to the reduction in the capacity, both reservoirs were provided with waterproofing made of PVC foil [45]. Their possible repair could be made under water [51].

On 27 June 2014, the project was officially inaugurated.

\section{System Operation Efficiency}

Since 27 June 2014, the island has been supplied experimentally from renewable energy sources. One year later, the energy system began its standard operation including test stages. On 9 August 2015, for two consecutive hours, the wind farm generated the energy that secured the demand of inhabitants using only RES. This was the first success of the new investment. It was assumed that the wind energy surplus was to be used to supply pumps such that water could be delivered from the lower reservoir to the upper reservoir. The filled upper reservoir was used as the energy storage [4,36].

As stated above, on the island of El Hierro, the wind speed reached a significant value, often even up to $13 \mathrm{~m} / \mathrm{s}$. The measuring data come from the monitoring system at the airport. The wind park is $3 \mathrm{~km}$ away from the airport; it is located on a hill and used the energy obtained at a greater height (the height of the terrain above sea level and the mast height of $64 \mathrm{~m}$ ); thus, the energy (directly proportionate to the wind speed in the third power) was greater here. However, there were windless periods which even covered 10-day cycles in this region, e.g., January or October 2016 [54,55]. Reference [54] presents examples of wind speed charts.

A similar solution was implemented on the island of Foula, in the Shetland archipelago and until July 2016, on the Japanese Okinawa Island. The solution on the island of Foula worked rather ineffectively, which was related to the temporary shut-downs of wind turbines during the breeding period of the birds living on the Island [56]. The Yanbaru power station in Kunigami, intended for the storage of seawater, was dismantled after seventeen years of operation as the electricity demand did not increase as expected [57].

El Hierro had a significant potential for energy self-sufficiency based on RES. The applied solution was unique. However, the size of the upper reservoir was determined by the geological conditions of the previously selected wind park area and the capacity of the La Caldera crater. The process of optimisation of its selection should be conducted as one of the first stages in the planned project, after the determination of the energy demand on the island. The reservoir capacity was adapted to the existing volcanic basin. The energy accumulation capacities, already significantly reduced in the project, were drastically decreased as a result of the rock formation weakness, which caused a considerable mismatch of the system components, and as a consequence of this, the lack of stabilization of the grid operation. A critical reference to this issue was made in Reference [43]. However, it must be taken into account that even if the initially-designed storage capacity was ensured $\left(550,000 \mathrm{~m}^{3}\right)$, the use of full wind power would not be possible. At present, it is estimated that the reservoir capacity should be at least 2.5 times greater than the one that has been assumed. If there is no wind, the hydroelectric plant can satisfy the needs of the inhabitants for no more than $48 \mathrm{~h}$ (some sources claim that it is actually $12 \mathrm{~h}$ ), using the accumulated energy.

Based on the three-year period of monitoring of the operation of the system on the island of El Hierro, it was concluded that RES did not cover $100 \%$ of the demand. The current deficiencies of the wind energy and the energy stored in the reservoir, whose capacity is too small, were supplemented from the diesel generator. However, according to the assumptions, it was only supposed to be used in exceptional circumstances.

However, a closer analysis of the monitoring results allowed us to conclude that the anticipated integration of hybrid system components was slow but effective.

In the year 2016, the operator conducted tests, which were aimed at such selection of the respective system components as to ensure the optimal operation and stabilisation of the network. His painstaking efforts brought results. 
The trend for RES's contribution to the island's energy economy was clearly growing. The average share of RES in energy production in the second half of 2015 was $19.4 \%$, and in 2016, it was $40.7 \%$. The press office of Red Electrica stated that in 2017, thanks to cooperation with Gorona del Viento, it was possible to increase the share of energy produced from RES on El Hierro to 46.5\%. In 2017, the best results were obtained in July, namely 79.4\% [55,58]. The average RES share in the first half of 2018 increased to $59.67 \%$. In addition, the successes of the island's short-term energy self-sufficiency with RES alone were recorded.

In August 2016, two periods were observed when $100 \%$ of the required electricity was generated from renewable energy sources (in $79 \mathrm{~h}$ total), and the average monthly percentage of energy from the RES was $55.6 \%$. It was higher than in the similar period of the previous year. On the other hand, during that period, the share of RES in the energy generation was lower than in July 2016 (65.9\%); there were breaks in the wind "delivery".

In 2018, the first period of supplying el Hierro with power exclusively from RES began at 11:20 p.m. on 15 January and lasted until 9:30 p.m. on 21 January, where next one, at the turn of January and February, covered 18 days.

Very favorable results were obtained in the summer months of 2018, especially in July [58]. On 3 July at 3:20 a.m., the system support by the diesel generator turned out to be unnecessary until 6:00 p.m. on 13 July. The diesel was disconnected again on 15 July at 00:10 a.m. until 1 August, inclusively, the island was supplied with RES. The share of hydroelectric power plant was $25-30 \%$, but, for example, on 29 July, this rose to as much as $90 \%$. The next RES periods without diesel were 5-13 August 2018, and 3-6 September 2018.

An interesting case occurred during the lack of wind energy supply on 28-29 March 2018. The windless period began just after midnight on 27 March 2018, and lasted for $36 \mathrm{~h}$. The improvement took place only in the afternoon of 29 March. In the period of windlessness, the task of securing the system with energy was successfully taken over by the hydroelectric power plant, which worked from 1:00 a.m. on 28 March, until 8:00 a.m. on 29 March, completely alone, without the support of diesel. After the start of the wind farm, part of the energy coming from this area was assigned to the current needs of the island, and some to the pump station; therefore, the diesel generators were also included in the work to obtain full power.

As stated in Reference [43], the necessity of a greater participation of the diesel generator in the operation of the system resulted from the deliberate reduction of wind farm capacity. The currently operating wind park with a capacity of $5 \times 2.3 \mathrm{MW}$ was adapted to the planned upper reservoir with a larger capacity. In the opinion of an expert, the wind capacity was intentionally reduced by the operator to $60 \%$ by turning off the turbines to ensure stable network operation.

Reference [55] presented a graph concerning the share of renewable energy and diesel in energy production in one of the tests carried out in June 2016. The graph shows periodic shutdown of wind turbines (e.g., on 7 June, for $14 \mathrm{~h}$, as well as on 23 June), or deliberate reduction of production capacity to about $7 \mathrm{MW}$, and in extreme cases, even to $5 \mathrm{MW}$. This caused the consumption of the reserve, and hence, the need to fill the tank for several days using wind energy, and the author of these considerations to conclude the need to eliminate the hydro component from the system. Whatever the motivations and prerequisites of the activities described in Reference [43], as a result of these research tests, a significant integration of both RES sources was achieved. Further considerations in this chapter confirm the groundlessness of the inference from Reference [43].

The analysis of the operation of the hydropower plant in the following months confirms its effectiveness, although it did not always work as spectacularly as in the case shown in Figure 10.

Both sources show integration and complement each other, while increasing the hydro activity and the longer elimination of the diesel generator. Power supply of the island was secured by both the wind energy and the potential energy of water. 


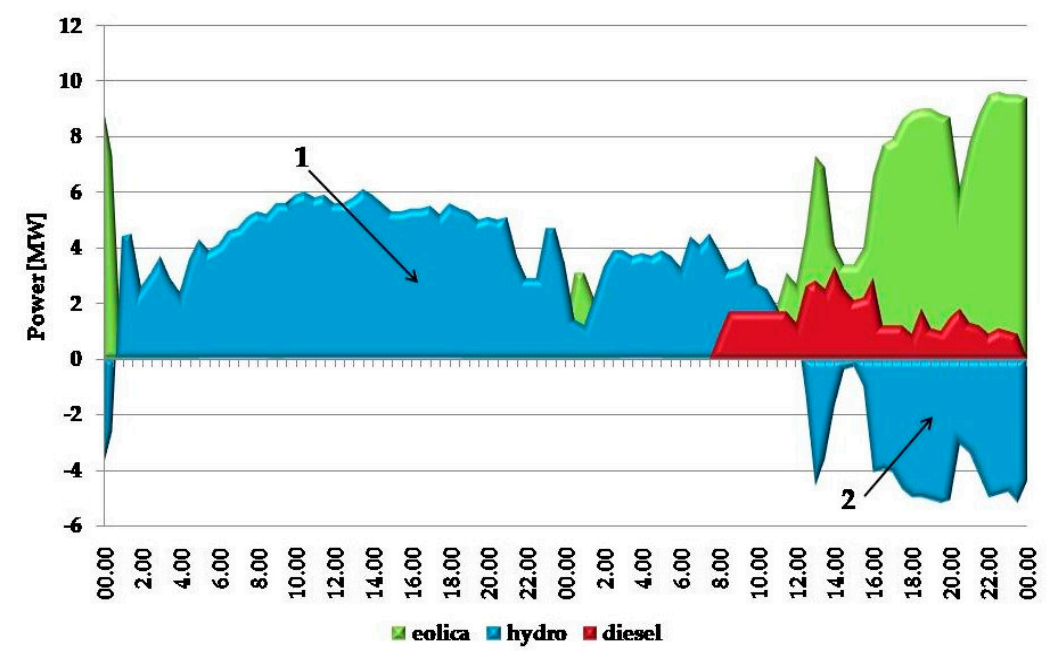

Figure 10. Operation of a hydroelectric plant in a windless period on 28-29 March 2018. Own study based on data from Red Eléctrica de España. Monitoring REE (Red Eléctrica de España) was carried out at 10-min intervals [58]. For the purpose of this work, the graphical relationship is shown in half-hourly intervals. Signs: (1) water power, and (2) water in the bottom tank (required wind to be pumped into the upper tank).

Figure 11 presents the average monthly generation of energy from renewable sources and diesel in the period from 27 June 2015 to the end of March 2018 [55,58,59].

At present, the island has the financial support from the government in Madrid. The cost of energy generation on the island of El Hierro is almost 3.5 times higher than in continental Spain. In this situation, which is undoubtedly difficult for the local community, the reduction in the prices of oil in the year 2015 turned out to be particularly advantageous [44].

In the following years, the share of RES in the energy balance increased significantly; nevertheless, the system on the island of El Hierro required further diagnosis, decisions, and modernization works.

The presented research and monitoring results allowed us to expect savings related to the reduction of the diesel share (before the implementation of the system of even 40,000 barrels per year), ensuring full self-sufficiency on the RES basis, and above all, the preservation of the valuable El Hierro biosphere reserve thanks to the reduction of $\mathrm{CO}_{2}$ emissions.

The problem was the water reservoirs, whose location was inappropriate, and this fact was previously ignored. In municipal locations (here: Valverde, the capital city of the island), it is prohibited to build water reservoirs of considerable sizes.

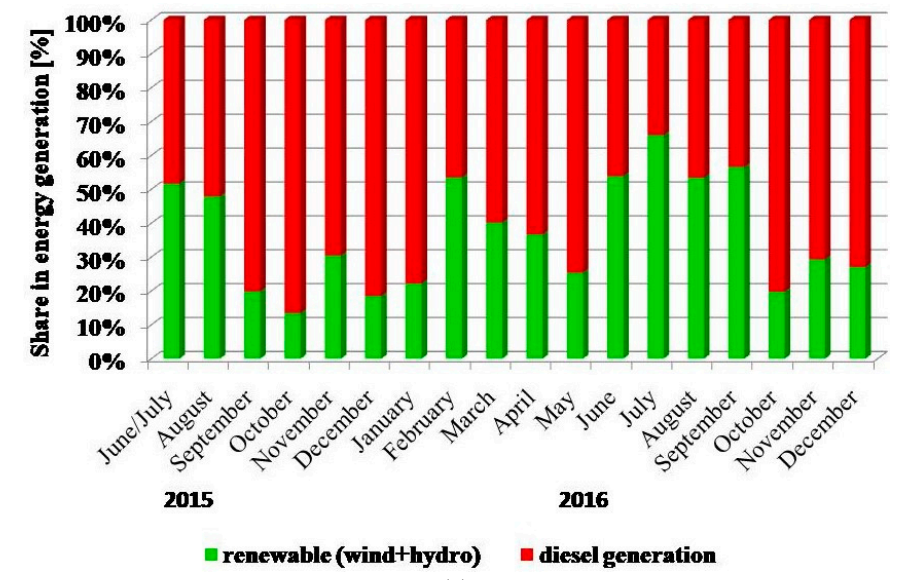

(a)

Figure 11. Cont. 


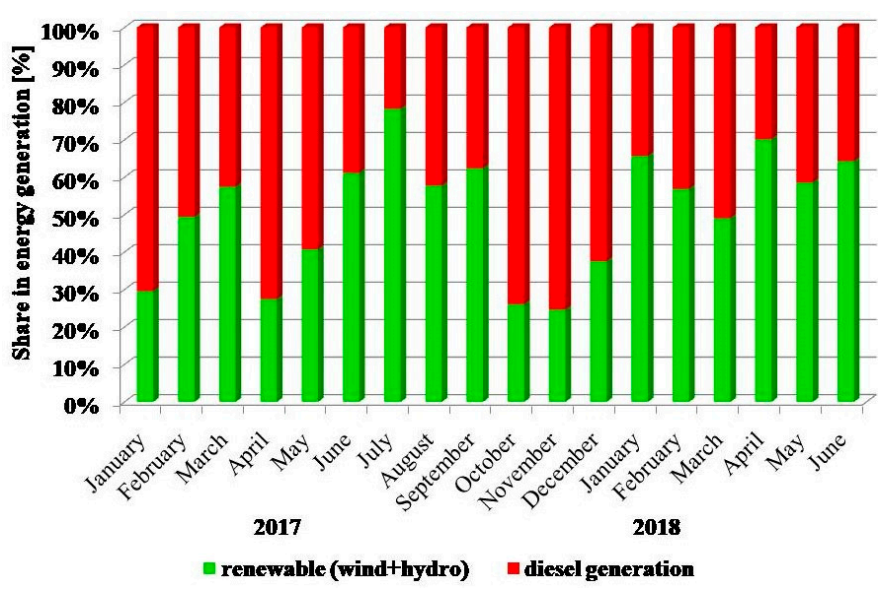

(b)

Figure 11. The share of individual sources in energy generation (a) from 27 June 2015, to the end of December 2016, (b) from 1 January 2017, to the end of June 2018, based on the own elaboration of the Red Eléctrica de España data.

\section{Possibilities of Improvement of El Hierro RES}

El Hierro is characterized by good solar exposure conditions. The number of solar hours during a month ranges between $140 \mathrm{~h}$ (January) and $234 \mathrm{~h}$ (August), which gives $2339 \mathrm{~h}$ in total during the entire year (an average figure over 30 years) (RES data). An average daily radiation energy exceeds $6 \mathrm{kWh} / \mathrm{m}^{2}$.

Figure 12 illustrates exemplary results of power density measurements for the solar radiation on El Hierro performed by the author on 25 July.

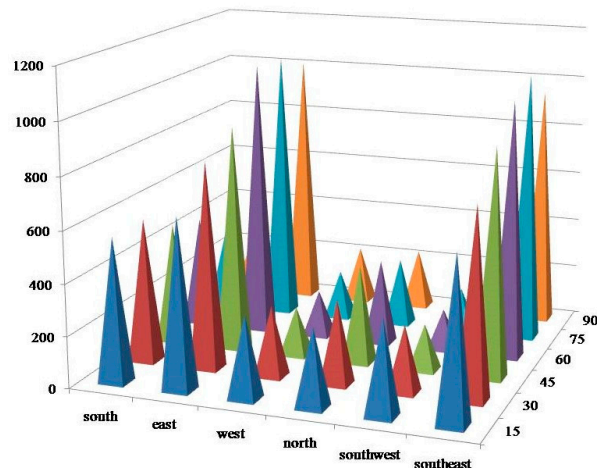

(a)

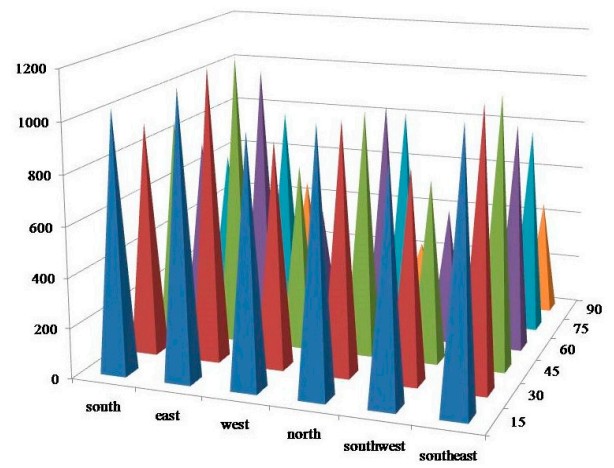

(c)

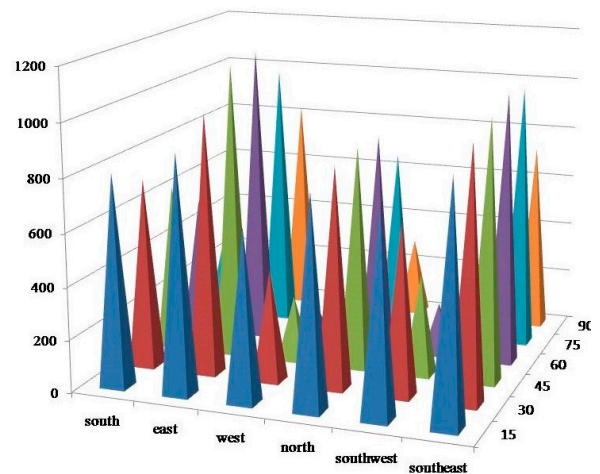

(b)

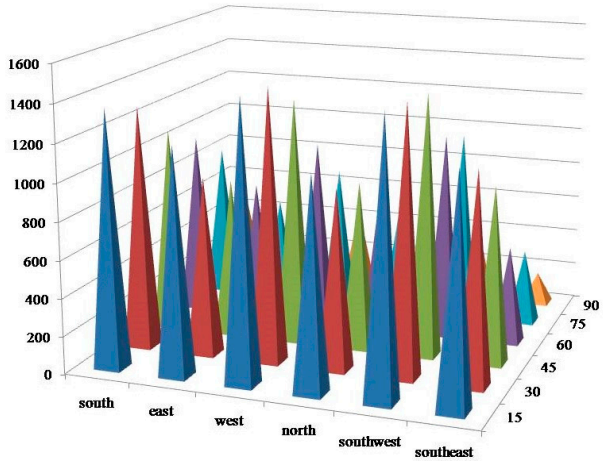

(d)

Figure 12. Measurements results of the power density of solar radiation carried out in El Hierro on 25 July, as functions of daytime and spatial orientation of the receiver (the angle to the ground and geographic direction): (a) 9 a.m., (b) 10.45 a.m., (c) 12.30 p.m., and (d), 2.15 p.m., based on the own research. 
The tests were performed for various seasons of the day and different spatial orientations of the receiver. Momentary values ranging between as much as 1200 and $1450 \mathrm{~W} / \mathrm{m}^{2}$ were obtained. This speaks well for the use of the solar energy in the system.

The results of the same measurements conducted by the author on Gran Canaria are similar. They were published in Reference [4].

\section{Summary}

The summary contains general conclusions and suggestions of the author.

1. In isolated locations, the share of energy from renewable resources in the overall energy balance may be limited by the requirements regarding the minimum conventional generator load, system stability, as well as the passive power and voltage control.

2. The hybrid system based on wind energy was introduced on El Hierro. It was supplemented using an energy storage within the pumped hydro storage. The solution did not ensure the assumed $100 \%$ energy self-sufficiency. In principle (per annum) the wind energy covered the demand of the inhabitants. However, there were fluctuations in its generation, including even windless periods (7-10 days) [4]. They were the result of the location of the island within the zone of impact of trade winds. Their speed (3.4-13.8 m/s) guaranteed very good working conditions for wind turbines. Their force of impact was the greatest in February and August. In October, the unstable impact of sirocco was observed (silence or very strong wind) [60]. As is the case with the majority of islands, El Hierro is not connected with the continental grid; therefore, it is necessary to use a diesel generator [4]. The plans stipulate the connection by means of an underwater cable (by the year 2050) and cooperation with regard to the energy balance between all islands of the archipelago [8]. The diversification of RES within a large area will allow the limitation of the stochastic nature of the impact of climatic changes on the operation of the system through the reciprocal compensation of profits and losses.

3. The problems with the achievement of energy self-sufficiency, which have been raised, are to a certain extent the result of mistakes and changes in the project, introduced already during the construction of the facility, in particular, the lack of the integration of the water reservoir capacities and the production capacities of the wind park, as well as the resulting necessity of the planned reduction in the capacity of the wind park to ensure the stability of the grid. The upper reservoir in the crater seemed exceptionally advantageous. If, however, the interference with the rock substrate aimed at its strengthening and protection against leakage turned out to be impossible (except waterproofing), other possibilities of increasing the effectiveness of the investment must be found.

4. Reference [43] specifies two proposals of very radical changes. The possibility of providing an additional capacity of the hydro reservoir was considered. Such a solution requires significant investment outlays and cannot be physically implemented under the El Hierro conditions. The second proposal refers to the total elimination of the hydroelectric plant from the system. In such a situation, the energy would come from the wind farm at the full operation of five turbines, and during the periods of shortage or fluctuations of wind, from the diesel generation. Leaving aside the issue of feasibility, none of the presented options seems to be satisfactory to ensure the fully reliability and effective operation of the RES hybrid system. The design and implementation of the system lasted a long time and required particularly high financial outlays. The facility of this importance must not function in an ineffective manner (maximum average annual share of RES without hydro-accumulation was $30 \%)$.

On the basis of detailed monitoring of the functioning of the system [58], as well as the situation presented in Figure 10, the suggestions of the expert from Reference [43] regarding the necessity of elimination of the hydroelectric power plant proved unjustified. The analysis of the operation of the hydroelectric plant in the following months confirmed its usefulness because it contributed to the power supply of the system, although it did not always work as spectacularly as on 28 and 29 March 2018. In cooperation with the wind farm, its share was often at the level of $25-30 \%$ RES, and sometimes even $90 \%$. 
5. To sum up, the results of the monitoring of energy sources on El Hierro and their share in the satisfaction of the island's energy demand, Figure 11 shows the continuous improvement of the GdV project [55]. The original priority objective, which was the share of RES at the level of $100 \%$, has not been accomplished yet. Studies and tests show that the wind park functions in a proper manner. The applied system, particularly the hydro-installation, requires further tests, the accurate monitoring and the possible modification. The process of integration of the system components is long-term.

6. As stated in Reference [8], El Hierro is an integral part of the Canary Islands' energy plan for powering the archipelago exclusively from RES. This effect will be achieved in 2050, thanks to the introduction of energy connections between the islands.

According to the authors of Reference [18], the hybrid energy systems based on the wind energy have an expected life of 65 years. The operational data of wind turbines guarantees 20 years; therefore, their prior modernization and replacement will be necessary.

7. Owing to the output from the renewable energy sources on the island of El Hierro, the emission of greenhouse gases was reduced on an annual basis, i.e., nitrogen oxides by 100 tonnes, carbon dioxide by 18,700 tonnes, and sulphur dioxide by 400 tonnes per year.

The suggestions of the author of this article point to several aspects of the case regarding the increase of the energy storage capacity on El Hierro (1-4) and to supplement the RES system with PV installations (5).

1. The storage of energy becomes necessary because of the fact that "supplies" from RES are neither stable nor synchronised with the demand for the energy. As well as the growing use of renewable sources in the generation of energy, the challenge is to find a reliable solution for its storage. In order to minimize the risk of power supply interferences, the storage of energy from RES should be implemented on two levels (development of the grid and improvement of the energy quality) [15]. The problem specifically refers to isolated sites (maintenance of the stable operation of the grid). Despite the great technological progress in the storage of energy, there are still many issues related to the applications in such locations. Possible selection of additional energy storage should be preceded by the detailed analysis, including economic aspects.

2. At present, pumped hydroelectric storages (PHS), characterized by high efficiency and reliability, are used on a large scale. In the majority of cases, it is recommended to introduce this technology to applications with long-lasting mass storage. On a global scale, the installed power in the PHS accumulation systems reaches almost 200 GW. PHS on El Hierro, if dimensioned properly, is particularly effective in the case of the long-lasting storage. In modern solutions of this type, there is an operable generator, which can also be used as an electric motor to power pumps (reduction in the costs of infrastructure), achieving $80 \%$ of the energy conversion efficiency. Then, the full power can be obtained even within $10 \mathrm{~s}$ during operation and during a maximum of one minute of shut-down. In the case under consideration, water is available. The cost of construction of a hydro-accumulator was lower in view of the formed upper reservoir [55].

3. On the other hand, in the case of sudden power loss, storage can stabilize voltage and frequency until the start of diesel generators. Such an accumulator can also be used to capture the excess energy from renewable sources and use it during the periods of high demand, which translates into short-term storage. For this purpose, lithium-ion batteries or lead-acid batteries are used. In not a long time, other modern technologies will become more and more widespread such as flow batteries with zinc bromide and water hybrid batteries [14]. They are characterized by low costs and the controllable capacity. In the case of the short-lasting and high demand for power, the FESS (flywheel energy storage system) is the best solution. Its response time is very short and its use in RES applications is suitable for balancing the network frequency. It also mitigates the effects of wind oscillation. For instance, on the islands of Flores and Graciosa, it ensures the share of RES in the energy balance at the level of even 75\% per year. In systems based on PV, FESS can be integrated with batteries in order to improve the efficiency of the system and extend the service life of the accumulator [61-63]. 
4. At present, fast development of electro-mobility is observed $[27,59,64,65]$. The "vehicle to grid" trends (the system which enables the bi-directional electricity flow between an electric vehicle and the grid) can also be implemented on El Hierro, where local authorities prepare the replacement of 6400 cars with electric vehicles, as well as 35 charging stations [60]. They can be used as energy storages [65]. In this case, the possibility of the quick response is particularly important; this technology complements well the long-term hydro storage. The batteries in the cars will collect energy and release it into the grid for the purpose of better balancing of the supply and demand. They will be charged at night and during the time of increased windiness. In Europe, studies have been conducted with regard to the possibility of using electric vehicles as energy storages in isolated energy systems.

The authors of Reference [27] reported that the share of transport in the total energy demand in São Miguel in the Azores archipelago was $40 \%$.

5. The suggestions of the author also indicate the possibility of complementing the system with the photovoltaic installation to supply the selected facilities, e.g., the pump system of the PHS. The validity of this concept is confirmed by the results of measurements of the solar radiation power density, performed by the author of the present study (Figure 12). On El Hierro, there are plans to utilize the energy of the sun, but in principle, they refer to collectors [60]. An example of the current effective use of the PV conversion on El Hierro is the lighthouse-Faro de Orchilla. The installation consists of $46 \mathrm{Si}$ modules with a unit power of $75 \mathrm{Wp}$ and the $3700 \mathrm{Ah}$ battery. Even the installation of such a low power, generating $5400 \mathrm{kWh}$, allows for eliminating 6.6 tons of $\mathrm{CO}_{2}$ per year from the environment [66]. The inhabitants of El Hierro also provide their houses with PV applications [67].

Funding: This research received no external funding.

Conflicts of Interest: The author declares no conflict of interest.

\section{References}

1. Garcia, A.; Meisen, P. Renewable Energy Potential of Small Island States, 1st ed.; GENI Global Energy Network Institute: San Diego, CA, USA, 2008; pp. 1-63.

2. Baipai, P.; Dash, V. Hybrid renewable energy systems for power generation instant-alone applications: A Review. Renew. Sustain. Energy Rev. 2012, 16, 2926-2939. [CrossRef]

3. Blechinger, E.; Sequin, R.; Cader, C.; Bertheau, P.; Breyer, C. Assesment of the global potential for renewable energy storage systems on small island. Energy Procedia 2014, 46, 325-331. [CrossRef]

4. Jastrzębska, G. Energia ze Źródeł Odnawialnych i Jej Wykorzystanie (Renewable Energy and Its Use), 1st ed.; Wydawnictwa Komunikacji i Łączności (WKŁ): Warszawa, Poland, 2017; pp. 1-334. ISBN 978-83-206-1983-6.

5. Erdinc, O.; Paterakisb, N.G.; Catalãob, J.P.S. Overview of insular power systems under increasing penetration of renewable energy sources: Opportunities and challenges. Renew. Sustain. Energy Rev. 2015, 52, 333-346. [CrossRef]

6. Chen, F.; Duic, N.; Alves, L.M.; da Graca Carvalho, M. Renewislands-Renewable energy solutions for islands. Renew. Sustain. Energy Rev. 2007, 11, 1888-1902. [CrossRef]

7. Marrero, G.A.; Ramos-Real, F.J. Electricity generation cost in isolated system: The complementarities of natural gas and renewables in the Canary Islands. Renew. Sustain. Energy Rev. 2010, 14, 2808-2818. [CrossRef]

8. De Otto, S.; Bevacqua, M.; Ferrán, F. Energy [R]evolution for the Canary Islands. Energy Design for Sustainable Island; Greenpeace: Stuttgart, Germany, 2015; pp. 1-32.

9. Santos Silva, C.A. Green Island Project Creating Value through Systems Thinking. Available online: https:/ / www.mitportugal.org/about/documents/events/2010-second-annual-symposium/726green-islands-project-carlos-silva-ist/file/ (accessed on 16 October 2018).

10. Celephis, S. Storage of non mainland grids and rotherspecial situations wind pumped storage hydro system. The future role of energy storage in south eastern Europe. In Proceedings of the Enlargement and Integration Action Workshop, Tirana, Albania, 21-22 October 2014; Publications Office of the European Union: Luxembourg, 2014; pp. 7-9. [CrossRef]

11. Clausen, N.-E.; Bindner, H.; Frandsen, S.; Hansen, J.C.; Lundsager, P. Isolated Systems with Wind Power an Implementation Guideline; Risø National Laboratory: Roskilde, Denmark, 2001; pp. 1-62. ISBN 87-550-2858-6. 
12. Hong, Y.-Y.; Lai, Y.-Z.; Chang, Y.-R.; Lee, Y.-D.; Lin, C.-H. Optimizing Energy Storage Capacity in Islanded Microgrids Using Immunity-Based Multiobjective Planning. Energies 2018, 11, 585. [CrossRef]

13. Electricity Storage and Renewables for Island Power: A Guide for Decision Makers; International Renewable Energy Agency: Abu Dhabi, UAE, 2012; pp. 1-45.

14. Escalante Soberanis, M.A.; Mithrush, T.; Bassam, A.; Merida, W. A sensitivity analysis to determine technical and economic feasibility of energy storage systems implementation: A flow battery case study. Renew. Energy 2018, 115, 547-557. [CrossRef]

15. Akhil, A.A.; Huff, G.; Currier, A.B.; Kaun, B.C.; Rastler, D.M.; Chen, S.B.; Cotter, A.L.; Bradshaw, D.T.; Gauntlett, W.D. Electricity Storage Handbook in Collaboration with NRECA; Sandia Report, DOE/EPRI SAND2013-5131; SAND: Albuquerque, NM, USA; Livermore, CA, USA, 2013; pp. 31, 135, 166.

16. San Martin, J.I.; Zamora, I.; San Martin, J.J.; Aperribay, V.; Eguia, P. Energy storage technologies for electric applications. In Proceedings of the International Conferrence on Renewable Energies and Power Quality (ICREPQ), Las Palmas de Gran Canaria, Spain, 13-15 April 2011; pp. 593-598. [CrossRef]

17. Overview of Storage Technologies. Available online: https:/ / www.projectsensible.eu/documents/overviewof-storage-technologies.pdf (accessed on 16 October 2018).

18. Rodrigues, E.; Godina, R.; Santos, S.; Bizuayehu, A.; Contreras, J.; Catalão, J. Energy storage systems supporting increased penetration of renewables in islanded systems. Energy 2014, 75, 265-280. [CrossRef]

19. Colthorpe, A. Hybrid power plant enabled for $65 \%$ renewable energy island Graciosa. Solar E Storage Live. 8 January 2018. Available online: https:/ / www.energy-storage.news/news/hybrid-power-plant-enabledfor-65-renewable-energy-island-graciosa (accessed on 16 October 2018).

20. Hoffmann, K.P. Die Inseln El Hierro und Graciosa kommen voran. Wirtschaft Träume vom Stromnetz ohne Diesel-Generator. Der Tagesspiegel. 9 May 2016. Available online: https: / /www.tagesspiegel.de/wirtschaft/traeume-vom-stromnetz-ohne-diesel-generator-die-inseln-elhierro-und-graciosa-kommen-voran/13566326.html (accessed on 16 October 2018).

21. Brazil, A. Tokelau-The First Country with 100\% Solar Energy. Available online: www.smainverted.com (accessed on 17 October 2018).

22. Guevara-Stone, L. Why a small German village bet big on renewable. GreenBiz, 13 September 2014.

23. Steel, W. Europe's largest battery energy storage project opens in Feldheim, Germany. Clean Technica, 21 September 2015.

24. Visit Samsø. Available online: www.visitsamsoe.dk (accessed on 29 September 2017).

25. Kumagai, J. The smartest, greenest grid. IEEE Spectr. 2013, 50, 42-47. [CrossRef]

26. Froese, M. Vestas and EDPR Install Wind Turbine-Coupled Hybrid Demonstrator. Available online: https://www.windpowerengineering.com/business-news-projects/vestas-edpr-install-windturbine-coupled-hybrid-demonstrator/ (accessed on 16 October 2018).

27. Osório, G.J.; Shafie-khah, M.; Lujano-Rojas, J.M.; Catalão, J.P.S. Scheduling Model for Renewable Energy Sources Integration in an Insular Power System. Energies 2018, 11, 144. [CrossRef]

28. Rodrigues, A.; Machado, D.; Dentinho, T. Electrical energy storage systems feasibility; the case of Terceira island. Sustainability 2017, 9, 1276. [CrossRef]

29. Hamsic, N.; Schmelter, A.; Mohd, A.; Ortjohann, E.; Schultze, E.; Tuckey, A.; Zimmermann, J. Increasing renewable energy penetration in isolated grids using a flywheel energy storage system. In Proceedings of the International Conference on Power Engineering, Energy and Electrical Drives (POWERENG), Setubal, Portugal, 12-14 April 2007; pp. 1-6.

30. Global Sustainable Electricity Partnership. Available online: www.phys.org/news/2016-05-turbinesgalapagos-millions-liters-diesel.html\#jCp (accessed on 1 June 2018).

31. Johnstone, H. Bonaire Island of green dream. Power Engineering International, 5 January 2010.

32. Conrad, M.D.; Esterly, S.; Bodell, T.; Jones, T. American Samoa: Energy Strategies; The National Renewable Energy Laboratory (NREL) Report for U.S.; Department of the Interior's Office of Insular Affairs (OIA): Washington, DC, USA, 2013.

33. Peters, A. The island of Samoa is going 100\% renewable-With Tesla's help. World Changing Ideas, 30 July 2018.

34. El Hierro; Otermin: Santa Cruz de Teneriffe, Spain, 2012; pp. 1-64. ISBN 8488187-41-6.

35. Fraver, L. Tiny spanish island nears its goal: 100 percent renewable energy. Heard on Weekend Edition Sunday, 28 September 2014. 
36. Lopez, E.; Garcia, C.M.; Minguell, C. El Hierro. La Isla del Fin del Mundo; Darana: Aljucer Murcia, Spain, 2012; pp. 1-119.

37. Mamede, H. El Hierro, a Reserva da Biosfera UNESCO que fica nos Confins do Mundo. Available online: https: / / www.ferias-espanha.pt/Santa-Cruz-de-Tenerife/artigos/el-hierro-a-reserva-da-biosferaunesco-que-fica-nos-confins-do-mundo (accessed on 16 October 2018).

38. Moreno, J.M. El Hierro, Reserva de la Biosfera; Turquesa: Santa Cruz de Tenerife, Spain, 2011; pp. 1-79; ISBN 978-84-92648-83-2.

39. Uceta, E.D. El Hierro, un edén en las Islas Canarias. Paisajes volcánicos y miradores asomados al océano en la ruta por esta isla declarada Reserva de la Biosfera. National Geographic Espana, 27 January 2017.

40. Gorona del Viento. Available online: www.goronadelviento.es (accessed on 20 November 2017).

41. Schallenberg-Rodriguez, J.; del Pino, J.N. Wind potential evaluation in the Canary Islands using GIS. In Proceedings of the International Conference on Renewable Energies and Power Quality (ICREPQ), Las Palmas de Gran Canaria, Spain, 13-15 April 2011; pp. 343-346.

42. Merino, J.; Veganzones, C.; Sanchez, J.A.; Martinez, S.; Platero, C.A. Power system stability of a small sized isolated network supplied by a combined wind-pumped storage generation system: A Case Study in the Canary Islands. Energies 2012, 5, 2351-2369. [CrossRef]

43. Andrews, R. An independent evaluation of the El Hierro wind \& pumped hydrosystem. Energy Matters, Energy, Environment and Policy, 23 February 2017.

44. Betzwieser, M. El Hierro: Enttäuschende Bilanz des Energieprojekt Gorona. La Palma AKTUELL, 9 January 2016.

45. Centeno, F.M.A.; Quevedo, A.M.; Gutierrez, J.M.Q.; Nueda, R.C.; Hart, J. Creating a hybrid hydro-wind system on spanish island. HRW-Hydro Review Worldwide, 9 January 2012; 1-6.

46. Enercon. Available online: www.enercon.de (accessed on 20 June 2018).

47. Polish Wind Energy. Available online: www.polishwindenergy.com (accessed on 20 June 2018).

48. Martnez-Lucas, G.; Sarasúa, J.I.; Sánchez-Fernández, J.E. Frequency regulation of a hybrid wind-hydro power plant in an isolated power system. Energies 2018, 11, 239. [CrossRef]

49. Declaración Ambiental Enero-Diciembre 2017. Available online: https://www.saitec.es/pdf/declaracion_ ambiental_2017.pdf (accessed on 16 October 2018).

50. For 18 Consecutive Days, the Island of El Hierro Covers $100 \%$ of Its Electricity Demand with Renewable Energy. Available online: https://www.ree.es/en/press-office/press-release/2018/02/18consecutive-days-island-el-hierro-covers-100-its-electricity-demand-with-renewable-energy (accessed on 16 October 2018).

51. Godina, R.; Rodrigues, E.M.G.; Matias, J.C.O.; Catalão, J.P.S. Sustainable energy system of El Hierro Island. Energy Power Qual. J. 2015, 13, 46-51. [CrossRef]

52. Blanco Fernandez, M.; Leiro Lopez, A.; Soriano Carillo, J.; Crespo Mucientes, M.; Zornberg, J.; Rico Arnaiz, G. Long-term performance of the laguna de Barlovento reservoir water-proofing using a PVC-P geomembrane. Ing. Civ. 2014, 171, 111-119.

53. Poulain, A.; Dreuzy, J.-R.; Goderniaux, P. Impermeabilizacion de la balsa de la Laguna de Barlovento con geomembrana de PVC-P: Evolucion a lo largo del tempo (Pump hydro energy storage systems (PHES) in groundwater flooded quarries). J. Hydrol. 2018, 559, 1002-1012. [CrossRef]

54. Andrews, R. El Hierro August 2016 performance update. Energy Matters Energy, Environment and Policy, 2 September 2016.

55. Andrews, R. El Hierro first quarter 2018 performance update. Energy Matters Energy, Environment and Policy, 6 April 2018.

56. Windfarmaction. Available online: https://windfarmaction.wordpress.com/2012/04/29/foula-fooled/ (accessed on 29 April 2018).

57. Experimental power plant in Kunigami dismantled. Japan Update, 29 July 2016.

58. Red Eléctrica de España Data. Available online: https://demanda.ree.es/movil/canarias/el_hierro/total/ 2018-03-28 (accessed on 7 October 2018).

59. Andrews, R. El Hierro second quarter 2018 performance update. Energy Matters Energy, Environment and Policy, 15 September 2018. 
60. Jastrzęskka, G. El Hierro-The first energetically self-sufficient region. In Proceedings of the 17th International Multidisciplinary Scientific Geoconference SGEM Energy and Clean Technologies, Vienna, Austria, 2017; pp. 651-658. [CrossRef]

61. Amiryar, M.E.; Pullen, K.R. A review of flywheel energy storage system technologies and their applications. Appl. Sci. 2017, 7, 286. [CrossRef]

62. Arani, A.A.K.; Zaker, B.; Gharehpetian, G.B. A control strategy for flywheel energy storage system for frequency stability improvement in islanded microgrid. Iran. J. Electr. Electron. Eng. 2017, 13, 10-21. [CrossRef]

63. Sebastián, R.; Peña Alzola, R. Flywheel energy storage systems: Review and simulation for an isolated wind power system. Renew. Sustain. Energy Rev. 2012, 16, 6803-6813. [CrossRef]

64. Marrero, G.; Perez, Y.; Petit, M.; Ramos-Real, F. Electric vehicle fleet contributions for isolated systems. The case of the Canary Islands. Int. J. Autom. Technol. Manag. 2015, 15, 171-193. [CrossRef]

65. Ramirez-Diaz, A.; Ramos Real, F.J.; Marrero, G.A.; Ramirez Diaz, A. Complementarity of electric vehicles and pumped-hydro as energy storage in small isolated energy systems: Case of La Palma, Canary Islands. J. Mod. Power Syst. Clean Energy 2016, 4, 604-614. [CrossRef]

66. Jastrzębska, G. Ogniwa Stoneczne. Budowa, Technologia i Zastosowanie (Solar Cells. Construction, Technology and Application), 1st ed.; Wydawnictwa Komunikacji i Łaczności (WKŁ): Warszawa, Poland, 2013; pp. 1-412. ISBN 978-83-206-1847-1.

67. Delle Femmine, L. The spanish island aiming to be 100\% renewable. El Pais: El Periódico Global, 28 March 2018.

(C) 2018 by the author. Licensee MDPI, Basel, Switzerland. This article is an open access article distributed under the terms and conditions of the Creative Commons Attribution (CC BY) license (http://creativecommons.org/licenses/by/4.0/). 